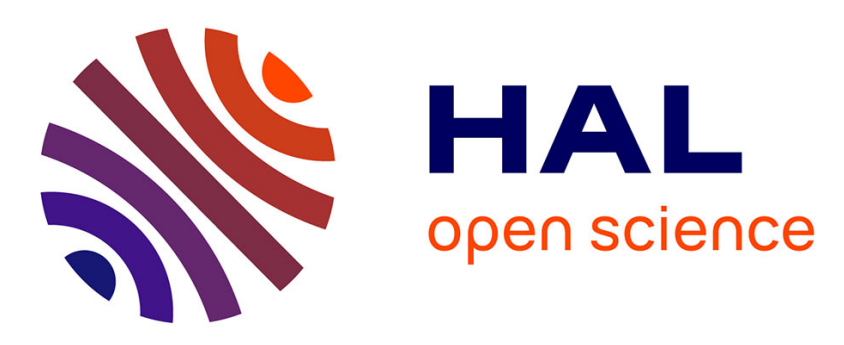

\title{
Allelopathy at the land/sea interface: microalgae and Brazilian pepper
}

Paul E. Hargraves

\section{To cite this version:}

Paul E. Hargraves. Allelopathy at the land/sea interface: microalgae and Brazilian pepper. Marine Environmental Research, 2008, 66 (5), pp.553. 10.1016/j.marenvres.2008.08.006 . hal-00563049

\section{HAL Id: hal-00563049 \\ https://hal.science/hal-00563049}

Submitted on 4 Feb 2011

HAL is a multi-disciplinary open access archive for the deposit and dissemination of scientific research documents, whether they are published or not. The documents may come from teaching and research institutions in France or abroad, or from public or private research centers.
L'archive ouverte pluridisciplinaire HAL, est destinée au dépôt et à la diffusion de documents scientifiques de niveau recherche, publiés ou non, émanant des établissements d'enseignement et de recherche français ou étrangers, des laboratoires publics ou privés. 


\section{Accepted Manuscript}

Allelopathy at the land/sea interface: microalgae and Brazilian pepper

Paul E. Hargraves

PII:

S0141-1136(08)00201-8

DOI:

10.1016/j.marenvres.2008.08.006

Reference:

MERE 3283

To appear in:

Marine Environmental Research

Received Date:

6 June 2008

Revised Date:

4 August 2008

Accepted Date:

18 August 2008

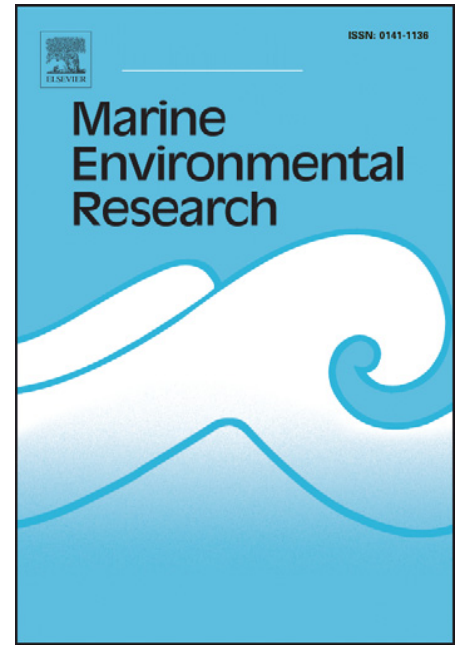

Please cite this article as: Hargraves, P.E., Allelopathy at the land/sea interface: microalgae and Brazilian pepper, Marine Environmental Research (2008), doi: 10.1016/j.marenvres.2008.08.006

This is a PDF file of an unedited manuscript that has been accepted for publication. As a service to our customers we are providing this early version of the manuscript. The manuscript will undergo copyediting, typesetting, and review of the resulting proof before it is published in its final form. Please note that during the production process errors may be discovered which could affect the content, and all legal disclaimers that apply to the journal pertain. 


\title{
Short communication \\ Allelopathy at the land/sea interface: microalgae and Brazilian pepper
}

\author{
Paul E. Hargraves \\ Harbor Branch Oceanographic Institution, Florida Atlantic University, Ft Pierce, FL (USA) 34946
}

Abstract

Microalgae are significant contributors to biodiversity and primary production in shallow coastal habitats. The invasive Brazilian pepper (Schinus terebinthifolius) can occupy former mangrove habitats in disturbed areas, and its allelopathic capability can affect growth rates of microalgae. The four microalgae tested against dilution extracts of Schinus fruits varied in their growth response, suggesting variable but unpredictable impacts on microalgal biodiversity, primary production, and community structure.

Keywords: microalgae; Brazilian pepper; Schinus terebinthifolius; diatom, Allelopathy; invasive species; land/sea interface

\section{Introduction}

The important role of estuarine microalgae, both benthic and planktonic, to ecosystem structure, primary productivity and coastal biodiversity is well established (Cahoon, 1999; Geider et al., 2001; Irgoien et al., 2005). In most coastal areas of the world, population and development pressures are modifying ecosystem structure and function (Selman et al., 2008; Vallega, 2000). The coasts of Florida are under particular stress from increases in coastal population, changes in land use, and various anthropogenic inputs to coastal waters. Historically mangrove forests and salt marsh communities have buffered the land/sea interface, but anthropogenic reduction of these buffer zones has often created niches into which invasive plants intrude, either as intentional or adventitious introductions. One such invader is the Brazilian pepper, Schinus terebinthifolius Raddi. It is particularly successful in invading disturbed mangrove habitats. This plant was introduced intentionally to the United States from South America for landscape purposes in the $19^{\text {th }}$ century (Olmstead and Yates, 1984), and is now found in Florida, Louisiana, Texas, California, Hawaii and Puerto Rico (Ferriter, 1997). There is genetic evidence that introduction to Florida has taken place at least twice (Williams et al., 2007), Copious fruit production occurs in November to February in Florida: birds (especially the migratory Turdus migratorious) and various small mammals consume the berries, and have contributed substantially to its spread (Ferriter, 1997).

Brazilian pepper is in the family Anacardiaceae. As with many members of this family, its leaves, sap, and fruits are copious producers of a variety of terpenes, flavonoids, organic acids, and other complex organic chemicals (Lloyd et al., 1977; Morton, 1978; Skopp and Schwenker, 1986). Many of these metabolites are potentially allelopathic and, given its hardiness, the plant is effective at displacing native vegetation including mangroves. Schinus terebinthifolius has invaded most successfully in Florida, where portions of the Everglades have been seriously impacted by replacement of native flora by Schinus (Ferriter, 1997). Along the coastline in low energy wave environments Schinus is often found in disturbed areas down to the high water line and sometimes slightly below, depending on water table. When it fruits, the berries are found in great abundance on intertidal mud flats in environments such as the Indian River Lagoon system on Florida's east coast. Since these mudflats and the overlying shallow waters at the land-sea interface are home to a highly productive and biodiverse (but as yet incompletely identified) microalgal flora (Hargraves, 2002), it would be useful to evaluate the impact of this invasive plant at the land/sea margin on microalgae. Accordingly, controlled experiments of berry extracts against locally isolated microalgae were undertaken to examine 
potential impact of allelopathic chemicals from Schinus berries on microalgal growth rates. This is the first research to focus on the impact of Schinus on microalgae.

\section{Methods}

In Florida, Brazilian pepper flowers primarily in October and the fruits mature in November to February (Ferriter, 1997). Ripe berries were collected at this time in 2006 from the high tide line in the central Indian River Lagoon near Vero Beach, Florida, and frozen at -25C until use. Concurrently, several benthic and planktonic microalgae were isolated from the IRL into culture. The isolation medium was local seawater, $0.2 \mu \mathrm{m}$ filtered, and enriched with ' $\mathrm{L}$ ' medium nutrients (Guillard and Hargraves, 1983). All experiments used the same batch of seawater base. Three diatoms and one dinoflagellate were chosen as test organisms.

Amphidinium carterae is a dinoflagellate that is mostly planktonic but is also common in the benthos. It is photosynthetic, an active swimmer, reportedly found worldwide in temperate and tropical waters (Steidinger and Tangen, 1997), though its real distribution may be more restricted due to confusion with other Amphidinium species (Murray et al., 2004). It can be responsible for fish kills and human toxicity, as it produces a number of toxic and bioactive compounds (Hallegraeff, 1993; Echigoya et al., 2005).

Palmerina hardmaniana is a large, solitary, and distinctive planktonic diatom, confined to the tropics, widespread but not often abundant. This apparently is the first time it has been cultivated.

Melosira nummuloides is primarily an epiphytic diatom of widespread geographic distribution in coastal waters, often adventitious in the plankton, forming uniseriate filaments of several to dozens of cells.

Pleurosigma salinarum is a widely distributed but rarely abundant benthic diatom, from coastal and estuarine waters, occasionally found in high conductivity fresh water, and adventitious in the plankton. It is actively motile on the surface of sediments in shallow water in temperate and tropical regions.

Thawed Schinus berries were macerated into 'L' medium (Guillard and Hargraves, 1983) at concentrations of $(\mathrm{W}: \mathrm{V}) 1: 10,1: 100$, and 1:1000, berry pulp filtered out, and dispensed as $50 \mathrm{ml}$ aliquots into $125 \mathrm{ml}$ Erlenmeyer flasks. Each treatment, plus septuplicate controls (' $\mathrm{L}$ ' medium, without Schinus berry extract) was replicated seven times for each microalgal species, for a total of 112 flasks. Flasks were inoculated with log phase cells of each tested microalgal species, and placed in a growth chamber at $22 \mathrm{C}, \sim 150 \mu \mathrm{mol} \mathrm{m}^{-2} \mathrm{~s}^{-1}$ and $16: 8 \mathrm{~L}: \mathrm{D}$ cycle. Initial cell concentrations for each species were 150+/-50 cells per ml. After 10 days, cells for each species were counted. Growth rates were calculated as $\mu\left(\right.$ day $\left.^{-1}\right)$ according to:

$$
\mu=\ln \mathrm{N}_{1} / \mathrm{N}_{0} \mathrm{t}
$$

where $\mathrm{N}_{0}$ and $\mathrm{N}_{1}$ represent cell density at the start and the end of the growth period, and $\mathrm{t}$ is the time between measurements in days. Preliminary growth rate measurements of the four microalgae suggested that under these growth conditions, log phase growth would not end for 24 weeks.

Growth rates and their significance were analyzed using Welch's t-test (Welch, 1947), an adaptation of Student's t-test for use with samples having possibly unequal variances.

\section{Results}


Results of the growth experiments are summarised in Table 1.

\section{(TABLE 1 INSERTED HERE)}

The four test microalgae were individually distinctive in their growth response. Melosira nummuloides was significantly inhibited by Schinus berry extract at 1:10 and 1:100 dilutions, but growth was equally significantly enhanced at 1:1000 dilution. No unusual cytological manifestations were seen at any of the treatments, although in two of the seven replicates in the 1:1000 treatment, auxospore formation was observed (not pictured). Pleurosigma $X X X X X X X X X$ grew at more than triple the rate of Melosira, and there was no difference between control growth rate and the extract dilutions.

The growth rate of Palmerina hardmaniana, the only holoplanktonic test species, was inhibited at all extract concentrations, though the results were not as definitive at the 1:100 dilution. As with Melosira nummuloides, growth rate was enhanced at the highest dilution level tested. The dinoflagellate Amphidinium carterae had the highest mean growth rate, but growth was inhibited at the more concentrated extract levels. With the 1:1000 dilution the difference was not significant compared to control flasks.

\section{Discussion}

Allelopathy is a common influence on community composition and function in both terrestrial (Scrivanti et al., 2003; Morgan and Overholt, 2005) and marine environments (Legrand et al., 2003; Graneli and Hansen, 2006). In the most comprehensive study to date of Brazilian pepper's potential allelopathic chemicals, 57 essential oils were identified in various parts of S. terebinthifolius, mostly as terpenoids, that accounted for $4.65 \% \mathrm{~W} / \mathrm{W}$ in ripe fruits (Almeida Barbosa et al., 2007). The dominant constituents were alpha-cadinol, elemol, betaphellandrene and germacrene-D. These authors also found some variability in sesquiterpene constituents among fruits, stems, and leaves (their Table 2), and among leaves over an annual cycle, but only in minor constituents and in minor amounts. For this preliminary research, all experiments were performed using ripe berries collected at one time at one location; thus growth inhibition could be different using material from other locations and times. It is presumed that these terpenoids have different solubilities in the seawater culture medium, and different volatilities.

It is unremarkable that different microalgae have different responses. The microalgal flora in this location exceeds $10^{2}$ species, and may be as high as $10^{3}$ species (Hargraves, 2002 and pers. obs.), and consists of a mix of epibenthic, epiphytic, epipsammic, and planktonic taxa in many different protistan divisions. Each species is likely to have specific environmental preferences. Thus, Pleurosigma, an epibenthic species adapted to microenvironments where water/sediment chemistry fluctuations can be frequent and rapid, is not significantly affected by Schinus extracts. Conversely, Melosira (an epiphyte raised above the benthos on seagrasses) and Palmerina (more common in open coastal loci) show inhibition at all dilutions tested. The dinoflagellate Amphidinium, thriving equally as epibenthic and planktonic, has a mixed response. It is noteworthy that the growth rates off both Melosira and Palmerina are significantly enhanced relative to controls at the 1:1000 dilution. This may be due to a stimulatory effect of very low concentrations of Schinus extract directly (non-terpenoid constituents are poorly known), or perhaps to a chelating effect on some micronutrient in the seawater medium.

In Florida, Brazilian pepper is classified as a category I invasive species (effectively disrupting terrestrial natural communities); its success is due jointly to allelopathic activity 
(Bennett and Habeck, 1991; Morgan and Overholt, 2005) and environmental eurytolerance (Ewe and Sternberg, 2007; Spector and Putz, 2006). Because it is now shown to have species-specific impacts on microalgae at the land-sea interface, the possibility of a cascade effect on primary productivity, biodiversity, and community structure needs evaluation. However, the consequences of dilution by hydrodynamic forces may mitigate any substantial impact.

\section{Acknowledgements}

The Smithsonian Marine Station, Ft Pierce, FL provided laboratory space. This is Harbor Branch Oceanographic Institution contribution \#XXXX, and SMS contribution \#XXXX. No support was provided by FLSG.

\section{References}

Almeida Barbosa, L.C., Demuner, A.J., Clements, A.D., Fonseca de Paula, V., and Ismail, F.M.D. 2007. Seasonal variation in the composition of volatile oils from Schinus terebinthifolius Raddi. Quimica Nova, 30, 1959-1965.

Bennett, F.D. and Habeck, D.H. 1991. Brazilian peppertree - Prospects for biological control in Florida. In: Center, T.D., Doren, R.F., Hofstetter, R.L., Myers, R.L., Whiteaker, L.D. (Eds.), Proceedings of the Symposium on Exotic Pest Plants. University of Miami, Miami, Fl. pp. 23-33.

Cahoon, L.B. 1999. The role of benthic microalgae in neritic ecosystems. Oceanography and Marine Biology Annual Review, 37, 47-86.

Echigoya, R., Rhodes, L., Oshima, Y., and Satake, M. 2005. The structures of five new antifungal and hemolytic amphidinol analogs from Amphidinium carterae collected in New Zealand. Harmful Algae, 4, 383-389.

Ewe, S., and Sternberg, L.S.L. 2007. Water uptake patterns of an invasive exotic plant in coastal saline habitats. Journal of Coastal Research, 23, 255-264.

Ferriter, A. (ed.) 1997. Brazilian peppertree management plan for Florida. Exotic Pest Plant Council, Brazilian Peppertree Task Force, Florida.

Geider, R.J., Delucia, E.H., Falkowski, P.G., Finzi, A.C., Grime, J.P., Grace, J., Kana, T.M., La Roche, J., Long, S.P., Osborne, B.A., Platt, T., Prentice, I.C., Raven, J.A., Schlesinger, W.H., Smetacek, V., Stuart, V., Sathyendranath, S., Thomas, R.B., Vogelmann, T.C., Williams, P., and Woodward, F.I. 2001. Primary productivity of planet earth: biological determinants and physical constraints in terrestrial and aquatic habitats. Global Change Biology, 7, 849-882.

Graneli, E. and Hansen, P.J. 2006. Allelopathy in harmful algae: a mechanism to compete for resources? In: Graneli, E., Turner, J.T., (Eds.), Ecology of Harmful Algae. Springer-Verlag Berlin, pp. 189-201.

Guillard, R.R.L. and Hargraves, P.E. 1983. Stichochrysis immobilis is a diatom, not a chrysophyte. Phycologia, 32, 234-236.

Hallegraeff, G.M., 1993. A review of harmful algal blooms and their apparent global increase. Phycologia, 32, 7999.

Hargraves, P.E. 2002. Diatoms of the Indian River Lagoon, Florida: An annotated account. Florida Scientist, 65, 225-244.

Irgoien, X. Huisman, J. and Harris, R.P. 2004. Global biodiversity patterns of marine phytoplankton and zooplankton. Nature 49: 863-867.

Legrand, C., Rengefors, K., Graneli, E., and Fistarol, G.O. 2003. Allelopathy in phytoplankton - biochemical, ecological, and evolutionary aspects. Phycologia, 42, 406-419. 
Lloyd, H.A., Jaouni, T., Evans, S. and Morton, J. 1977. Terpenes of Schinus terebinthifolius. Phytochemistry, 16, 1301-1302.

Morgan, E.C. and Overholt, W.A. 2005. Potential allelopathic effects of Brazilian pepper (Schinus terebinthifolius Raddi, Anacardiaceae) aqueous extract on germinationa and growth of selected Florida native plants. Journal of the Torrey Botanical Society, 132, 11-15.

Morton, J. 1978. Brazilian pepper - its impact on people, animals, and the environment. Economic Botany, 32, 353359.

Murray, S., M. Flo Jorgensen, M., N. Daugbjerg, N., and L. Rhodes, L. 2004. Amphidinium revisited. II. Resolving species boundaries in the Amphidinium operculatum species complex (Dinophyceae), including the descriptions of Amphidinium trulla sp.nov. and Amphidinium gibbosum comb. nov. Journal of Phycology, 40, 566-582.

Olmstead, I. and Yates, S. 1984. Florida’s pepper problem. Garden, 8, 20-23.

Scrivanti, L.R., Zunino, M.P., and Zygadio, J.A. 2003. Tagetes minuta and Schinus areira essential oils as allelopathic agents. Biochemical Systematics and Ecology, 31, 563-572.

Selman, M., Greenhalgh, S., Diaz, R., and Sugg, Z. 2008. Eutrophication and hypoxia in coastal areas: A global assessment of the state of knowledge. WRI Policy Notes 1: 1-6.

Skopp. G. and Schwenker, G.. 1986. Bioflavonoid from Schinus terebinthifolius . Zeitschrift fuer Naturforschung, B41, 1479-1482.

Spector, T., and Putz, F.E. 2006. Biomechanical plasticity facilitates invasion of maritime forests in the southern USDA by Brazilian pepper (Schinus terebinthifolius). Biological Invasions, 8, 255-260.

Steidinger, K., and Tangen, K. 1997. Dinoflagellates. In: Tomas, C.R. (Ed.), Identifying Marine Phytoplankton. Academic Press, Inc., San Diego, CA. pp. 387-598.

Vallega, A. 2000. Sustainable Ocean Governance: A Geographical Perspective. Routledge.Taylor and Francis Group, London 304pp.

Welch, B.L. 1947. The generalization of "student's" problem when several different population variances are involved. Biometrika, 34, 28-35.

Williams, D.A., Muchugu, E., Overholt, W.A., and Cuda, J.P. 2007. Colonization patterns of the invasive Brazilian peppertree, Schinus terebinthifolius, in Florida. Heredity, 98, 284-293. 
Table 1. Growth rates $[\mu /$ day] of microalgae challenged with Schinus terebinthifolius extracts. Significance level $(*)$ is the likelihood that differences in growth rate are by coincidence.

\begin{tabular}{ccccc}
\hline & control & $1: 10$ dilution & $1: 100$ dilution & $1: 1000$ dilutior \\
$\begin{array}{c}\text { Melosira } \\
\text { mean }\end{array}$ & 0.35 & 0.23 & 0.23 & 0.46 \\
$\begin{array}{c}\text { range } \\
\text { significance* }\end{array}$ & $0.29-0.41$ & $0.20-0.27$ & $0.20-0.33$ & $0.40-0.54$ \\
& & $<.01$ & $<.05$ & $<.05$ \\
Pleurosigma & & & & \\
mean & 1.29 & 1.31 & 1.49 & 1.24 \\
range & $1.0-1.6$ & $1.1-1.5$ & $1.2-1.8$ & $1.0-1.4$ \\
significance* & & $\mathrm{NS}$ & $\mathrm{NS}$ & $\mathrm{NS}$
\end{tabular}

\section{Palmerina}

$\begin{array}{ccccc}\text { mean } & 1.03 & 0.73 & 0.94 & 1.21 \\ \text { range } & 0.8-1.3 & 0.3-1.1 & 0.8-1.2 & 1.0-1.5 \\ \text { significance* } & & <.05 & <.10 & <.05\end{array}$

\section{Amphidinium}

\begin{tabular}{ccccc} 
mean & 1.43 & 1.23 & 1.36 & 1.32 \\
range & $1.2-1.6$ & $1.1-1.5$ & $1.1-1.4$ & $1.0-1.8$ \\
significance* & & $<.05$ & $<.05$ & NS \\
\hline
\end{tabular}

